\title{
BE KLIPES dan BE BLAUK \\ KULINER SERANGGA AIR TAWAR LANGKA di BALI
}

\author{
I Gusti Ayu Ari Agustini dan Anastasia Sulistyawati \\ Email: asigaari@yahoo.com dan prof.sulistyawati@yahoo.com \\ POLITEKNIK INTERNASIONAL BALI
}

\begin{abstract}
Abstrak
Perubahan sistem pertanian berpengaruh terhadap keberadaan dari sumber daya hayati. Tujuan penulisan ini adalah: (1) Mengetahui gambaran umum kuliner khas Bali dari serangga air tawar. 2) Memeroleh strategi menjaga sumber daya hayati kuliner khas Bali dari serangga air tawar. Teknik pengumpulan data adalah melalui wawancara dan studi pustaka. Teori digunakan teori revitalisasi dan budi daya.

Hasil penelitian menunjukkan olahan masakan yang terbuat dari serangga air bernama klipes dan blauk, sebagai makanan pendamping. Lauk ini merupakan sumber protein, vitamin, dan gizi, sekaligus sumber energi utama bagi tubuh. Strategi menjaga sumber daya utama kuliner adalah menggunakan sistem pertanian organik. Penerapan pertanian organik secara luas sekaligus dapat menjadi penyelamatan sumber daya alami dan hayati dari bahan utama be klipes dan be blauk. Strategi berikutnya adalah melalui budi daya yang hanya dapat dilakukan pada blauk.
\end{abstract}

Kata kunci: kuliner, serangga air tawar, langka, Bali.

\section{Abstract}

The modifications in agricultural systems affect the existence of biological resources. The purposes of this research are : (1) to know the general description of Balinese culinary specialties from freshwater insects. 2) to obtain a strategy of maintaining the culinary biological resources. The data collection techniques used in this research are interviews and literature study and the theories are the theory of revitalization and cultivation theory.

The results showed that processed dishes that are made from some water insects, locally named klipes and blauk. They are both sources of protein, vitamins, and nutrition therefore an energy source for the body. The strategy of maintaining the culinary is by using an organic farming system. The widespread application of the system, at the same time can be a saving of natural and biological resources from the main ingredients which are clipped and mixed. The other strategy is through cultivation which can only be done on be blauk.

Keywords: culinary, freshwater insects, rare, Bali. 


\section{Pendahuluan}

Serangga adalah makhluk unik, yang memiliki peran sangat fundamental terhadap siklus karbon global melalui perannya sebagai dekomposer yang handal. Serangga bersama-sama dengan semut dan cacing tanah merupakan "mesin tanah" yang sangat esensial, di mana mikroba dan tumbuhan bergantung padanya. Meski beberapa jenis serangga memakan material organik pada tanah, akan tetapi mayoritas ia adalah pemakan bagian tanaman yang mati atau membusuk, seperti serasah daun, akar, maupun potongan-potongan kayu. Seperti diketahui, bagian tanaman yang mati tersebut sangat tinggi kandungan selulose dan ligninnya sehingga sulit didekomposisi (http://biogen.litbang.pertanian. go.id/2012/08/serangga-plasma-nutfah-yang-luar-biasa/).

Ukuran tubuh serangga yang kecil tidak menghalangi kemampuannya dalam beradaptasi dan sekaligus bertahan terhadap guncangan alam, sehingga serangga masih ditemukan sampai sekarang. Namun hingga kini baru sekitar 1.000.000 spesies serangga yang sudah diidentifikasi, dan masih cukup banyak serangga yang belum berhasil diidentifikasi (http://www.dinosaur-facts.com).

Keragaman dan kelimpahan serangga tersebut kemudian mendorong para ahli untuk menyimpulkan bahwa serangga mempunyai peran yang amat vital di lingkungan. Para ahli membuktikan bahwa serangga (herbivora) adalah converter energi kimia tumbuhan yang pertama (sebelum dimangsa oleh musuh alaminya) sekaligus menjadi musuh alami tumbuhan, penyerbuk, pemangsa organisme lain (termasuk serangga lain), perombak bahan organik (ingat, jika tidak ada rayap atau ulat sagu, maka dunia ini akan penuh oleh timbunan batang-batang dan seresah tumbuhan), dan juga sebagai bahan pakan ternak dan pangan. Banyak serangga yang mampu menghasilkan bahan-bahan yang dapat dimanfaatkan oleh 
manusia, misalnya madu, royal jelly, dan sutra (https://rumahserangga.wo rdpress.com/2011/07/07/dunia-serangga-yang-unik/).

Selain yang hidup di darat, sebagian dari jenis serangga itu adalah hidup di air, salah satunya adalah klipes dan blauk. Blauk (kini-kini) adalah serangga air yang sering menjadi predator benih ikan yang ganas. Blauk merupakan fase larva dari serangga capung yang hidup di dalam air. Selanjutnya setelah fase post larva berubah menjadi serangga capung yang hidup di darat dan tidak lagi menjadi predator langsung benih ikan (https://lelesangkuriangabah.wordpress.com/2012/05/04/kini-kini-larvacapung-musuh-peternak-lele/). Demikian pula dengan klipes (jenis serangga yang disebut kumbang air), pada masa fase larvanya dikenal dengan jubel (ucrit) menjadi predator benih ikan yang ganas.

Potensi besar dari serangga ini sejak lampau sudah biasa dimanfaatkan menjadi masakan lauk sederhana bagi masyarakat pedesaan di Nusantara ini. Namun, dewasa ini sudah berhasil dikembangkan menjadi kuliner yang lezat dengan mengolahnya menjadi kripik/peyek bahkan sampai bisa ekspor ke luar negeri).

Di banyak negara Asia, Afrika dan Amerika Latin lainnya serangga juga sudah menjadi makanan yang sering disantap. Selain itu, kumbang yang dilapisi dengan glasir gula juga banyak dijual di toko-toko kue di Jerman. (https://www.dw.com/id/sehatnya-menyantap-serangga/a17650121). Sedangkan di Bali masyarakat petani di pedesaan juga sejak lampau sudah biasa membuat lauk dari beberapa jenis serangga air yang disebut klipes (cybister) dan blauk (kini-kini), yang diolah dengan berbagai cara sehingga menjadi makanan menarik dan enak (https://lelesangkuriangabah.wordpress.com/2012/05/04/kini-kini-larvacapung-musuh-peternak-lele/).

Berdasarkan latar belakang masalah di atas maka terdapat beberapa masalah berkaitan dengan menu Kuliner Tradisional Bali (KTB) dari 
bahan utama serangga jenis Klipes (cybister) dan Blauk (kini-kini), yaitu: 1) Bagaimanakah gambaran umum kuliner khas Bali dari serangga air tawar? 2) Bagaimanakah strategi menjaga sumber daya hayati kuliner khas Bali dari serangga air tawar?

\section{Teori dan Metode}

Teori selanjutnya adalah teori revitalisasi, yaitu upaya untuk memvitalkan kembali suatu kawasan yang dulunya pernah vital hidup akan tetapi mengalami kemunduran dan degradasi. Revitalisasi fisik dapat meningkatkan kondisi fisik lingkungan, namun tidak untuk jangka panjang. Untuk itu, tetap diperlukan perbaikan dan peningkatan aktivitas ekonomi yang merujuk kepada aspek sosial budaya serta aspek lingkungan. Hal tersebut mutlak diperlukan karena melalui pemanfaatan yang produktif, diharapkan akan terbentuklah sebuah mekanisme perawatan dan kontrol yang langgeng terhadap suatu lingkungan (habitat). Teori budi daya adalah usaha yang dilakukan di suatu tempat tertentu pada suatu kawasan budi daya secara berkesinambungan untuk hewan peliharaan dan produk hewan. Teori ini dipergunakan untuk mengkaji strategi pembudidayaan serangga air tawar, khususnya blauk.

Penelitian ini memakai pendekatan holistik berarti cara melihat atau memandang sesuatu sebagai suatu kebulatan yang utuh. Penelitian ini bersifat studi pustaka yaitu pengumpulan data dilakukan di perpustakaan Politeknik Internasional Bali, baik melalui buku-buku KTB dan buku-buku manajemen dalam bidang kuliner pariwisata serta ditunjang informasi yang tersedia di internet. Informasi langsung diperoleh dari informan kunci dari generasi lampau yang pernah menikmati dan berpengalaman langsung memasak kuliner yang kini sudah menjadi langka tersebut.

Jenis penelitian adalah deskriptif analitis (descriptive analitic) karena penelitian ini bertujuan untuk mendapatkan gambaran dan informasi 
tentang potensi jenis-jenis kuliner tradisional Bali yang sudah langka dan mengetahui permasalahan kendala yang dihadapinya dalam pengembangannya untuk mencari cara pemecahannya. Penelitian deskriptif analitis bertujuan untuk memeroleh secara jelas tentang suatu situasi atau keadaan tertentu yang ada di lapangan melalui pengumpulan data, dalam hal ini khususnya cara membuat kuliner yang sudah langka ini dan kaitannya dengan penyebab terjadinya keterbatasan potensi pasokan bahan alam dan hayati yang ada di daerah Bali saat ini.

\section{Pembahasan}

Pada pembahasan ini akan dibahas mengenai hasil dari penelitian dan menjawab kedua masalah yang ada dalam penelitian ini. Gambaran umum Kuliner Khas Bali dari serangga air tawar ini akan memaparkan mulai dari lokasi hidup serangga berupa be klipes dan be blauk, kandungan gizi, sejarah, dan cara menjadikan masakan dengan bahan utama klipes dan blauk dan bahan dan bumbu yang diperlukan hingga cara penyajiannya.

\subsection{Gambaran Umum Be Klipes}

Menurut kalangan ilmiah, serangga memang bisa menjadi sumber pangan penting untuk masa depan. Tak hanya lezat, menurut peneliti Belanda Arnold van Huis serangga juga lebih ramah lingkungan. Lebih dari 70 persen lahan pertanian di seluruh dunia habis digunakan untuk hewan ternak. Ketika permintaan atas daging meningkat, manusia perlu sumber protein baru, dan adalah serangga dari segi diet cukup serupa, bahkan lebih baik. Salah satu jenis serangga yang termasuk jenis kumbang air tawar adalah klipes (kumbang air mirip kepik ukuran besar), di masa lampau sudah biasa dikomsumsi dalam bentuk klipes goreng oleh masyarakat petani pedesaan di Bali, yang hidup dari pertanian sawah. 


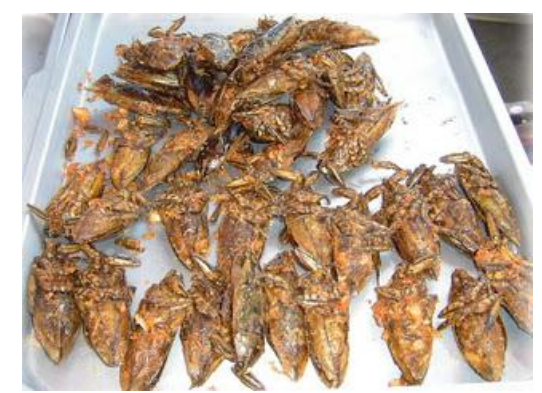

Gambar 1. Klipes Goreng Berbalut Tepung Sumber: https://www.anehdidunia.com/2012/05/lezatnyamakanan-dari-serangga.html

Be Klipes ini di Thailand juga sudah umum dikenal dengan nama Maengda, berukuran cukup besar, sekitar 4-6 cm. Kuliner Maengda sudah biasa dijajakan di pinggir jalan di sana, tapi karena bentuknya yang sepintas terlihat seperti kecoak dan ukurannya yang besar, maka tak semua orang tertarik mencicipi kuliner serangga air yang satu ini. Sajian maengda ini biasanya diolah dengan cara digoreng kering ataupun direbus dan diberi garam untuk menambah rasa. Untuk menikmati maengda rebus, cukup tarik hingga lepas sayap-sayapnya. Kemudian pisahkan antara tubuh serangga dan kepala, seluruh daging yang terdapat di bagian tubuh serangga dapat dinikmati. Daging serangga ini cukup lezat seperti telur dadar dengan cita rasa kayu manis yang kuat. Selain bagian tubuh serangga, bagian kepalanya yang digoreng kering juga bisa dimakan. Rasanya seperti kepiting dengan rasa kayu manis yang kuat (htt ps://www.pinterpandai.com/kuliner-makanan-serangga-goreng-thailand/).

\section{1) Lingkungan Lokasi}

Lokasi hidup klipes (cybister) adalah di lingkungan perairan berlumpur, sawah, danau, parit, kolam. Klipes pada waktu masih larva berbentuk ulat (disebut jubel dan cucut) sangat ganas sebagai pemangsa mahkluk air yang berukuran lebih kecil. Predator benih ikan ini umumnya merupakan binatang tingkat tinggi yang langsung mengganggu atau mengancam kehidupan ikan. Benih ikan yang 
berukuran kecil dengan kondisi tubuh yang masih lemah dan cenderung hidup berkelompok, merupakan santapan empuk jubel ketimbang ikan yang sudah berukuran dewasa. Selain itu, benih ikan yang masih berukuran kecil tidak mampu menghindar apalagi melakukan perlawanan terhadap predator bernama jubel ini (http//: lelesangkuriang217.blogspot.com/2013/08/).

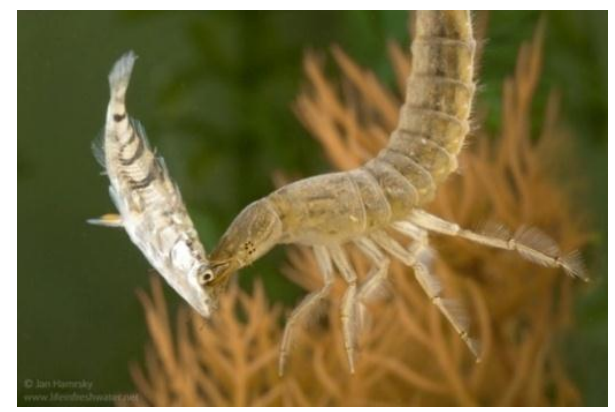

Gambar 2. Larva Klipes (Jubel) Memangsa Benih Ikan Sumber: http://lifeinfreshwater.net/ngg_tag/diving-beetle/nggallery/page/2

Bila sudah bermetamorfosa menjadi klipes (cybister), tidak lagi seganas waktu masih menjadi larva (jubel atau ucrit) dengan lingkungan hidup tetap di air berlumpur, tetapi kadang-kadang juga bisa hidup di darat dan suka terbang di malam hari mencari sumber sinar (lampu). Pada musim klipes biasanya sebagian dari para warga petani pedesaan memanfaatkannya sebagai pilihan lauk alternatif dan selingan yang murah untuk menghemat keuangan dapur. Bagi masyarakat petani yang hidup dalam ekonomi kemiskinan mengonsumsi daging hewan atau ikan dirasa cukup mewah dan mahal, karena itu pada musimnya sedapat mungkin didapatkan pengganti yang mudah dicari di sekitar lingkungannya. 


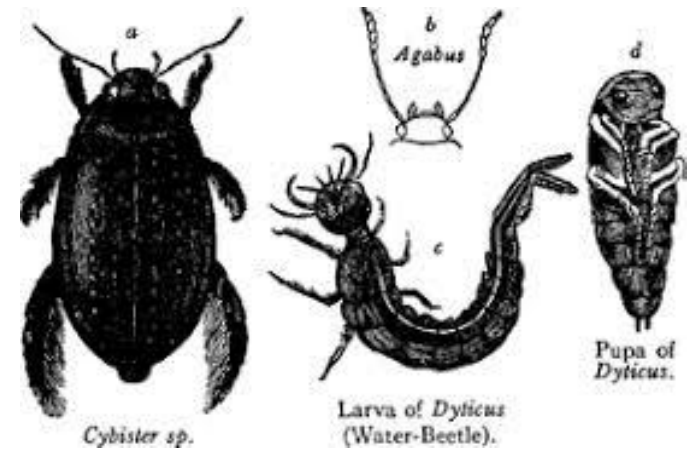

Gambar 3. Metamorfosis Cybister

Sumber: https://anzdoc.com/mata-kuliah-parasit-dan-penyakit-ikan-insects-danarachnids.html

\section{2) Kandungan Gizi}

Serangga mengandung banyak asam lemak tidak jenuh, banyak zat besi, lemak, mineral dan vitamin. Pemanfaatan serangga sebagai bahan pangan yang didengungkan oleh Organisasi pangan dunia Food and Agriculture Organization (FAO) sebenarnya sudah lama dilakukan oleh masyarakat petani di Bali, dengan memasak klipes (kumbang air) dan disantap sambil minum tuak. Di negaranegara Asia lainnya juga sudah sering disantap sambil minum bir, sebagai santapan istimewa Asia. Serangga adalah sumber protein dan energi. 100 gram serangga mengandung 610 kilo kalori, lebih banyak dari cokelat, 38 gram protein dan 46 gram lemak.

John Coupland, Profesor ilmu pangan dari Penn State University mengungkapkan: Pertama, serangga mengandung banyak protein. Jangkrik mengandung 65 persen protein, sedangkan daging sapi hanya 50 persen. Kandungan lemak dalam serangga juga rendah.

Alasan lainnya, serangga mudah ditemukan dan berlimpah karena banyak pilihan terdiri dari 300 lebih spesies. Alasan terakhir adalah karena rasanya yang lezat. Orang-orang yang mengonsumsi serangga menggambarkan rasa serangga pedas memiliki rasa mirip dengan udang atau ayam. Badan PBB yang membidangi pangan dan 
pertanian (FAO) mengungkapkan bahwa kehidupan serangga lebih ramah lingkungan dibandingkan dengan hewan lainnya (https://tirto. id/mau-kudapan-bergizi-makan-serangga-saja-codF).

\section{3) Sejarah Be Klipes Goreng}

Masyarakat petani sawah (Subak Basah) di Bali pada masa lampau dalam rutinitas kehidupannya tidak akan pernah merasa asing dengan mahkluk air bersayap ganda yang disebut klipes ini. Baik waktu mulai membajak sawah sampai saat pasca tanam padi banyak klipes muncul di lahan persawahannya. Berdasarkan ilmu warisan leluhurnya klipes dapat dimasak dijadikan lauk atau camilan sebagai pengganti daging hewan yang mahal. Otomatis saat membajak sawah bila muncul klipes dari balik tanah yang digarapnya, maka sambil bekerja juga langsung dipakai kesempatan menangkap klipes, dimasukan ke dalam wadah khusus, yang paling sederhana berupa kantong ketupat.

Tetapi bila sudah waktu pasca tanam, di air berlumpur sawah akan makin banyak muncul klipes dan jubel, sehingga bisa dimanfaatkan khusus untuk menangkap klipes dengan memakai semacam alat saringan perangkap bertangkai panjang dari anyaman bambu atau lidi yang disebut seser. Cukup dengan cara menarik seser di permukaan lumpur dari atas pematang sawah maka klipes akan terperangkap, setelah diangkat selanjutnya cepat ditangkap dari atas seser dengan tangan dan dimasukan ke wadah khusus. Serangga air ini disukai oleh warga sebagai camilan dalam menemani minum tuak di warung atau kedai tuak.

4) Bahan dan Bumbu Be Klipes Goreng

Terdapat beberapa bahan dan bumbu yang diperlukan untuk menjadikan klipes menjadi kuliner yang nikmat. Bahan-bahan utama yang diperlukan adalah klipes setengah $\mathrm{kg}$, tepung beras secukupnya, 
garam, dan air bersih. Sedangkan bumbu yang diperlukan adalah bawang putih lima siung, kencur satu ruas jari, dan cabe rawit dua biji semua bumbu dihaluskan.

\section{5) Cara Membuat Be Klipes Goreng}

Klipes dicuci bersih, lalu bumbu halus ditambah air bersih dan dimasukan tepung beras sedikit demi sedikit sambil diaduk hingga merata, jangan lupa ditambah garam secukupnya. Setelah itu masukan klipes yang telah dicuci bersih ke dalam adonan bumbu dan tepung, biarkan terbenam beberapa menit ke dalam adonan sampai bumbu meresap ke dalam klipes, baru digoreng.

\section{6) Cara Memasak Be Klipes Goreng}

Siapkan wajan di tungku dapur dan minyak goreng lalu dipanaskan. Setelah minyak cukup panas baru klipes yang dibalut tepung bumbu dimasukan ke dalam minyak secara bertahap. Gorenglah klipes sampai garing, lalu angkat ke dalam wadah gorengan yang benar-benar kering agar tidak layu. Goreng bertahap bagian demi bagian sampai habis, lalu matikan api. Klipes goreng balut tepung siap disajikan. Klipes juga bisa digoreng kering tanpa tepung, terlebih dahulu klipes direndam ke dalam cairan bumbu halus selama beberapa menit sampai bumbu meresap, baru digoreng kering.

\section{7) Cara Penyajian Be Klipes Goreng}

Klipes goreng balut tepung ini enaknya disajikan bersama dengan nasi putih dan sambal matah serta sayur gonda. Klipes goreng balut tepung ini juga enak disajikan sebagai camilan saat minum tuak ramerame. Waktu penyajian yang baik adalah pada waktu siang hari saat makan siang, setelah selesai bekerja di sawah, atau di sore hari saat minum tuak sambil mebombong (mengelus dan melatih adu ayam jago). 


\subsection{Gambaran Umum Be Blauk}

Kuliner tradisional Bali yang sudah sangat langka selain Be Klipes adalah Be Blauk (nimfa capung). Lauk ini dibuat dari larva capung (blauk) yang banyak hidup di wilayah perairan berlumpur terutama sawah, danau dan parit di Bali. Jenis lauk dari Blauk sudah sangat langka akibat punahnya populasi jenis serangga ini yang disebabkan penggunaan pestisida dalam perawatan padi di sawah (https://www.boom bastis.com/makanan-dari-serangga/4105).

Metamorfosis Capung terjadi 3 tahapan, mulai dari tahapan telur selama 2 hingga 7 hari. Nimfa akan hidup di perairan selama 4 minggu hingga 4 bulan tergantung jenis capung. Capung dewasa selama 2 hingga 4 bulan.

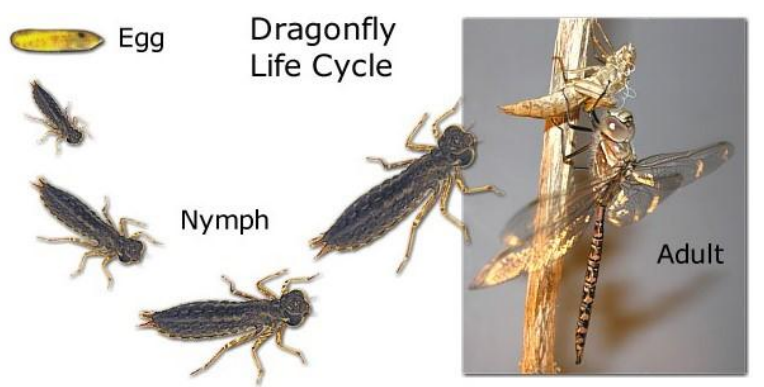

Gambar 4. Proses Metamorphosis Blauk atau Nimfa Capung Sumber: https://pasberita.com/metamorfosis-atau-daur-hidup-capung/

\section{1) Lokasi Be Blauk}

Be Blauk sering dimasak oleh masyarakat petani sawah di pedesaan Bali. Hal ini disebabkan oleh keberadaan blauk hanya ditemukan di lingkungan perairan yang berlumpur (sawah) yang bersih atau bebas dari zat beracun. Keberadaan blauk dalam proses metamorphosis capung mempunyai peran sebagai salah satu bioindikator lingkungan perairan sawah, selain jubel. Jika di lingkungan sekitar suatu tempat tidak ditemukan lagi, dapat dipastikan ekosistem perairan di sana telah tercemar (http://berita. upi.edu/capung-bioindikator-dari-bangsa-odonata/). 
Keberadaan capung secara umum sebenarnya sangat membantu petani di sawah karena capung suka memburu beberapa hama tanaman, seperti ngengat dan walang sangit. Selain itu, nimfa capung yang disebut blauk ini juga suka memangsa hama serangga wereng dan jentik-jentik nyamuk yang ada pada air bersih seperti nyamuk malaria. Sama seperti saat menjadi larva, nimfa capung masih sering berganti kulit hingga 12 kali (http://makhluk-air.blog spot.co.id/2015/01/kini-kini.html). Blauk biasanya diam di ceruk kecil yang masih tergenang air saat sawah yang sedang dikeringkan.

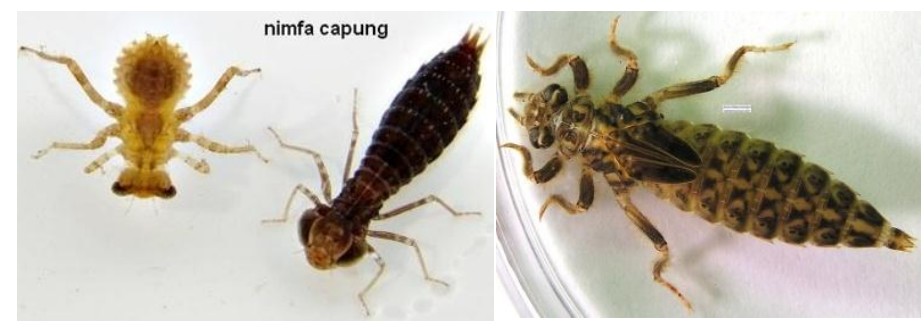

Gambar 5. Kokak (Warna Putih) dan Blauk (Abu-Abu Sampai Hitam) Sumber:

https://www.google.co.id/search?q=proses+metamorfosa+capung+dari+sawah+sampai $+\&$ tbm

Cara menangkapnya cukup pakai cekot sambil berdiri di pematang. Alat cekot yang dipakai menangkap blauk dibuat dari anyaman lidi janur yang dibentuk seperti perangkap saring berkantung yang diberi tangkai bambu cukup panjang disebut seser. Oleh karena itu, proses penangkapan blauk ini disebut nyeser, karena caranya adalah dengan menyosorkan seser ke air berlumpur di sawah dari atas pematang sawah, lalu diangkat digoyang agar air dan lumpur jatuh dan hanya tersaring serangga predator ini untuk ditangkap dimasukin botol atau jerigen kecil sebagai penampungan.

2) Kandungan Gizi Be Blauk

Larva capung jarum atau kinjeng yang juga disebut undur-undur (Myrmeleon sp) karena berjalan mundur mengandung zat 
sulfonylurea, yang memiliki khasiat obat membantu mengatasi diabetes, stroke, darah tinggi, dan rematik (http://jhonthit.blogspot. co.id/2014//fakta-menarik-tentang-undur-undur.html). Tetapi belum ada orang yang menulis mengenai kandungan larva capung lainnya yang disebut blauk (kini-kini) secara spesifik.

Secara umum FAO mengatakan kandungan gizi dan nutrisi dari serangga tak kalah dari daging. Serangga banyak mengandung serat dan mikronutrisi seperti zat besi atau magnesium. Serangga juga bisa dijadikan suplemen makanan bagi anak-anak yang kekurangan gizi, karena serangga kaya asam lemak yang menghasilkan nutrisi (https://tirto.id/serangga-akan-jadi-penyelamat-krisis-pangan-cuBH). 3) Sejarah Be Blauk

Anak atau larva capung ini dikenal dengan blauk di Bali. Blauk ini sering ditangkap oleh para petani dijadikan kuliner murah untuk menghemat keuangan dapur. Alat penangkapnya adalah cekot atau serok kecil bertangkai panjang terbuat dari anyaman serat bambu atau lidi janur disebut seser. Blauk biasanya hidup dan diam di cerok kecil lumpur yang masih tergenang air saat sawah dikeringkan.

Untuk menangkapnya, seseorang sambil berdiri di pematang lalu mengayunkan dan menarik seser di lumpur berair langsung diangkat agar airnya jatuh dari saringan seser, sehingga blauk-nya mudah ditangkap tangan dimasukan ke kantong khusus. Waktu penangkapan selama tengah hari sampai saat istirahat kerja, petani biasanya mendapat cukup banyak blauk untuk dibawa pulang, dimasak untuk makan sore keluarga. Rasanya sedikit lebih enak dari capung panggang atau pepes daun kunyit.

4) Bahan dan bumbu Be Blauk

Bahan untuk membuat gerangasem blauk di antaranya adalah blauk setengah kg, dua liter air bersih untuk kuah gerangasem, bahan 
bambu, garam secukupnya, penyedap (satu sendok teh gula pasir). Untuk bumbu yang diperlukan adalah basa genep yang terdiri dari lengkuas/laos satu potong (seruas jari), kunir satu potong, jahe satu potong, bangle satu potong dan kencur satu potong. Bahan pelengkapnya seperti bawang merah 12 siung, bawang putih tujuh siung, cabe rawit lima buah atau lebih kalau ingin tambah pedas, garam secukupnya, terasi matang empat sendok teh, dan kuncinya adalah rempah-rempah seperti ketumbar/lada dua sendok teh, merica hitam dua sendok teh, merica putih dua sendok teh, kemiri yang sudah disangrai lima butir, daun jeruk lima lembar, jinten, gula merah, dan semua dihaluskan sampai lembut.

\section{5) Cara Membuat Be Blauk}

Di Bali blauk sering dimasak menjadi gerangasem blauk atau brengkes blauk. Cara membuat gerangasem blauk adalah cuci blauk dengan air bersih beberapa kali, kemudian blauk diseduh dengan air mendidih agar mati dan tiriskan. Siapkan bumbu base genep dan haluskan sampai lembi (lembut). Lalu siapkan kuah gerangasem dengan dua liter air dan masukkan bumbu halus tersebut dan masak kembali sampai mendidih.

\section{6) Cara Memasak Be Blauk}

Blauk yang telah direbus dan ditiriskan kemudian dimasukan ke dalam kuah yang telah mendidih yang telah berisi bumbu base genep, lalu dipanaskan kembali sampai mendidih berunglangkali hingga blauk-nya menjadi matang dan bumbunya meresap. Atau bisa juga blauk yang telah ditiriskan lalu dibalut dengan bumbu yang telah dihaluskan di atas potongan daun pisang, kemudian langsung dibungkus dan dikukus menjadi brengkes blauk (Surayin, 2007: 68).

Namun, blauk yang disebut sayok oleh masyarakat di sekitar Danau Linow di Tomohon, Sulawesi Utara biasa dikonsumsi dengan 
bumbu pedas, yang terdiri atas merica, cabe rawit, bawah merah dan bawang putih yang dihaluskan kemudian ditumis dengan cukup air serta diberi sayur bawang pre lalu dicampur sayok, dimasak sampai kuahnya kering. Di daerah Tiongkok, nimfa capung ini cuma digoreng kering saja, dan sudah menjadi makanan yang umum di masyarakat sehingga menjadi komoditas yang diperdagangkan. Blauk goreng ini juga sudah dikenal luas di beberapa daerah di Indonesia (https://manfaat.co.id/manfaat-capung).

\section{7) Cara Penyajian Be Blauk}

Blauk sudah sering dimasak di Indonesia, yang umum dikonsumsi masyarakat di daerah Manado (Sulawesi), Tabanan (Bali), dan Blitar (Jatim) menjadi bahan makanan alternatif di luar hewan dan ikan. Blauk telah diolah menjadi kuliner berkuah gerangasem atau pepes menjadi brengkes atau digoreng kering paling enak disajikan sebagai lauk yang dimakan bersama nasi putih dan sambal matah. Gerangasem blauk atau brengkes blauk atau blauk goreng pedes ini paling tepat disajikan pada siang hari, selai perut sedang laparnya.

\subsection{Strategi Menjaga Sumber Daya Hayati Kuliner Khas Bali dari Serangga Air Tawar}

Klipes dan blauk merupakan serangga air yang perlu untuk dikembangkan karena merupakan bahan utama dari kuliner khas Bali. Berkurangnya populasi serangga ini dikarenakan sering dianggap sebagai hama yang dibasmi dengan berbagai bahan kimia.

Klipes saat ini sulit dibudidayakan karena perlu lingkungan alam yang khusus yaitu tanah berair atau berlumpur sebagai tempat hidup dan berkembang biak. Klipes juga sangat peka terhadap pestisida atau zat kimia beracum lain, sehingga menjadi indikator kebersihan dan kesehatan 
lingkungan perairan di sawah. Dengan perubahan pola pertanian yang menggunakan obat-obatan yang mengandung zat kimia beracun, menyebabkan semakin punahnya klipes sejak dari masa fase larvanya yang disebut jubel. Cara satu-satunya yang dapat ditempuh untuk mengembalikan populasi kedua serangga air tawar ini di sawah atau subak (satu kawasan pertanian) adalah dengan menjaga lingkungan hidup alaminya secara ketat, tanpa menggunakan obatan-obatan kimia yang beracun dalam perawatan tanaman di sawah. Agar hal itu bisa dilaksanakan perlu dibuat peraturan oleh warga subak berkaitan dengan larangan penggunaan bahan-bahan berbahaya bagi lingkungan hidup, dan mencari alternatif pemanfaatan sumber daya alam atau musuh-musuh alaminya dalam pemberantasan hama tanaman di sawah.

Tidak seperti klipes, blauk lebih mudah dijaga kelestariannya karena dapat dibudidayakan. Dari hasil pengamatan capung yang dipelihara di luar ruangan (dibuatkan semacam gubuk bambu beratap seng, beralaskan tanah dan tanpa dinding), setelah bermetamorfosis hingga fase imago (capung), akan didapatkan lubang-lubang sarang yang baru berukuran kecil di samping lubang-lubang sarang yang sudah ada. Akan tetapi, hal tersebut masih dipengaruhi oleh faktor-faktor lingkungan seperti, kenyamanan, ketersediaan pakan, cahaya, dan siraman air.

Capung yang selama hidupnya mendapatkan cukup makanan, cahaya dengan sedikit gangguan, setelah mencapai fase imago (capung), biasanya akan kawin dan meninggalkan telurnya di samping sarang-sarang yang sudah ada.

\section{Penutup}

Tradisi Kuliner Bali sangat berkaitan dengan sumber daya hayati di lingkungan sekitar, yang berkaitan dengan sektor pertanian basah. Perubahan sistem pertanian berpengaruh terhadap keberadaan dari sumber 
daya hayati yang memang rentan terhadap zat-zat kimia beracun akibat dari pemberantasan hama tanaman. Hal penting yang perlu ditekankan dalam kaitannya dengan hama adalah bagaimana mengubah cara pandang masyarakat tentang serangga sebagai hama serta pemahaman untuk tidak menghakimi serangga yang menjadi hama tersebut secara membabi buta atau membasminya dengan menggunakan pestisida/insektisida.

Petani Indonesia di beberapa daerah sudah sangat familiar dengan pengendalian hayati yang memanfaatkan serangga yang berperan sebagai musuh alami, yaitu predator maupun parasitoid. Sehingga ketika menjumpai hama pada lahannya, tidak serta-merta membasminya, akan tetapi bersedia menerapkan prinsip-prinsip Pengendalian Hama Terpadu. Predator alami seperti capung, belalang sembah, laba-laba, dan semut, sangat membantu menekan populasi hama di lapangan.

Seperti diketahui blauk adalah fase larva capung yang bermanfaat dalam ekosistem pertanian. Penyelamatan populasi capung juga berarti menyelamatkan populasi blauk dan klipes di sawah, danau, dan parit. Dengan membudayakan sistem pertanian organik (tanpa penggunaan obatobatan kimia dan bahan-bahan beracun) diharapkan dapat mengembalikan populasi alami klipes dan blauk di sawah. Penerapan pertanian organik secara luas sekaligus dapat menjadi penyelamatan sumber daya alami dan hayati dari bahan be klipes dan be blauk sebagai salah satu alternatife terbarukan bagi pilihan pemenuhan protein, vitamin dan gizi bagi manusia di dunia.

\section{Daftar Pustaka}

Ariani, Risa Panti. 2017. Mengenal Kuliner Bali. (Ed.1, Cet.1.). Depok: Rajawali Pers.

Kusumawati, Rika; Putra, Winkanda Satria. 2013. Resep Masakan Nusantara Favorit dari Aceh Hingga Papua. Yogyakarta: C.V. Andi Offset.

Pitanatri, Putu Diah Sastri; Putra, I Nyoman Darma. 2016. Wisata Kuliner Atribut Baru Destinasi Ubud. Denpasar: Jagatpress bekerja sama dengan Program Studi Magister Kajian Pariwisata Universitas Udayana. 
Remen, I Ketut. 1987. Olah-olahan Paebatan Bali. Tanpa penerbit.

Surayin, Ida Ayu. 2007. Masakan Bali. Surabaya: Paramita.

Wrasiati, Luh Putu; Wijaya, I Made Anom Sutrisna; Suter, I Ketut; Wiranatha, A.A. Putu Suryawan. 2017. Kuliner Tradisional Bali (Balinese Traditional Kulinary). Denpasar: Udayana University Press.

\section{Informan:}

1. Nama

: I Wayan Sabeh

Alamat : Lingkungan Tengah, Desa Adat Lukluk, Mengwi, Badung, Bali

Umur : 78 tahun

2. Nama : Made Kesiar

Alamat : Lingkungan Badung, Desa Adat Lukluk, Mengwi, Badung, Bali

Umur : $\quad$ : 76 tahun

3. Nama : Ni Nyoman Pineh

Alamat : Lingkungan Badung, Desa Adat Lukluk, Mengwi, Badung, Bali

Umur $\quad: 70$ tahun

4. Nama : Wayan Kariawan

Alamat : Lingkungan Badung, Desa Adat Lukluk, Mengwi, Badung, Bali

Umur : 54 tahun

\section{Internet:}

Abror, Abah. 2012. Kini-Kini (Larva Capung) Musuh Peternak Lele. (serial online). [cited 2017 Juli. 3]. Available from URL: https://lelesangku riangabah.wordpress.com/2012/05/04/kini-kini-larva-capung-musuhpeternak- lele/.

Anonim. 2012. Lezatnya Makanan dari Serangga. (serial online). [cited 2017 Juli. 3]. Available from URL: https://www.anehdidunia.com/2012/05/ lezatnya-makanan-dari-serangga.html.

Anonim. 2014. Mengolah Sampah adalah Ibadah. (serial online). [cited 2017 Juli. 3]. Available from URL: http://programlingkungan.blogspot.co. $\mathrm{id} / 2014 /$.

Anonim. 2016. Kini-Kini Atau Yang Sering Disebut Larva Capung. (serial online). [cited 2017 Juli. 3]. Available from URL: http://itesindia.blog spot.co.id/2016/12/kini-kini-atau-yang-sering -disebut.html.

Anonim. 2017. Fun Dinosaur Facts for Kids. (serial online). [cited 2017 Juli. 3]. Available from URL: http://www.dinosaur-facts.com.

Anonim. 2017. Serangga Sebagai Makanan. (serial online). [cited 2017 Juli. 3]. Available from URL: https://www.pinterpandai.com/ kuliner-makananserangga-goreng-thailand/.

Apriana, Dwi. 2017. Proses Metamorfosis atau Daur Hidup Capung Beserta Gambar dan Penjelasannya. (serial online). [cited 2017 Juli. 3]. Available from URL: https://pasberita.com/metamor fosis-atau-daur-hidupcapung/. 
BB Biogen. 2012. Serangga Plasma Nutfah yang Luar Biasa. (serial online). [cited 2017 Juli. 3]. Available from URL: http://biogen. litbang.pertani an.go.id/2012/08/serangga-plasma-nutfah-yang-luar-biasa/.

Jhonthit. 2014. Fakta Menarik Tentang Khasiat dan Manfaat Undur Undur. (serial online). [cited 2017 Juli. 3]. Available from URL: http://jhonthit. blogspot.co.id/2014/12/fakta-menarik-tentang-undur-undur.html.

Miyanti. 2015. Capung, Bio-Indikator Dari Bangsa Odonata. (serial online). [cited 2017 Juli. 3]. Available from URL: http://berita.upi.edu/capung-bioindikator-dari-bangsa-odonata/.

Nugroho, Adi. 2015. 7 Makanan Khas Indonesia yang Terbuat dari Serangga! (serial online). [cited 2017 Juli. 3]. Available from URL: https://www. boombastis.com/makanan-dari-serangga/4105

Osterath, Brigitte. 2014. Sehatnya Menyantap Serangga. (serial online). [cited 2017 Juli. 3]. Available from URL: https://www.dw.com/id/sehatnyamenyantap-serangga/a-17650121.

Putra, Nugroho S. 2011. Dunia serangga yang unik.... (serial online). [cited 2017 Juli. 3]. Available from URL: https://rumahserangga.wordpress.com/ 2011/07/07/dunia-serangga-yang-unik/.

QQ, Empang. 2016. Hama Ikan: Ucrit. (serial online). [cited 2017 Juli. 3]. Available from URL: https://empangqq.com/2016/06/25/hama-ikanucrit/.

Rohman, Ridwan Abdul. 2015. Kini-Kini. (serial online). [cited 2017 Juli. 3]. Available from URL: http://makhluk-air.blogspot.co.id/2015/01/kinikini.html.

Sartika, Eli. 2017. 4 Manfaat Capung Untuk Kehidupan Manusia dan Lingkungan Sekitar. (serial online). [cited 2017 Juli. 3]. Available from URL: https://manfaat.co.id/manfaat-capung.

Suada, I wayan. 2015. Sayur Favoritku. (serial online). [cited 2017 Juli. 3]. Available from URL: http://iansuada.com/?cat=12.

Suryari, Fachri. 2013. Siklus Hidup Capung. (serial online). [cited 2017 Juli. 3]. Available from URL: https://fachrisuryari.wordpress.com/2013/01/28/ siklus-hidup-capung/.

Wibisono, Nuran. 2017. Serangga Akan Jadi Penyelamat Krisis Pangan. (serial online). [cited 2017 Juli. 3]. Available from URL: https://tirto.id/serang ga-akan-jadi-penyelamat-krisis-pangan-cuBH.

Wikipedia. 2017. Budi Daya. (serial online). [cited 2017 Ags. 2]. Available from URL: https://id.wikipedia.org/wiki/Budi_daya.

\section{Profil Penulis}

I Gusti Ayu Ari Agustini, S.ST.Par.,M.M. lahir di Denpasar, 9 Agustus 1980. Menyelesaikan Pendidikan Sekolah Dasar hingga SMU di Denpasar. Program S1 dan Magister (S2) yang ditempuh adalah Bidang Pariwisata di Universitas Udayana. Memiliki pengalaman kerja di beberapa bidang terkait pariwisata dan seni kuliner. Saat ini menjadi Dosen Program D3 Studi Seni Kuliner di Politeknik Internasional Bali dan memiliki usaha bidang kuliner. Dapat dihubingi melalui asigaari@yahoo.com. 
Prof.Dr.Ir. A Sulistyawati, M.S.,M.M.,M.Mis.,D.Th.,Ph.D.,D.Ag(c) memperoleh gelar BAE, Bidang Arsitektur di Universitas Udayana (UNUD) pada tahun 1971. Melanjutkan pendidikan S1 Bidang Arsitektur di UNUD dan ITS pada tahun 1980. S2 Bidang Ilmu Lingkungan dan Ekologi Manusia di Universitas Indonesia tahun 1989; Program S3 Arsitektur di Oxford Brookes-UK pada tahun 1995; Program S2 Manajeman pada tahun 2000 di Sekolah Tinggi Ilmu Ekonomi Widya Jayakarta, Jakarta; Program S2 (2010) dan S3 (2013) Bidang Agama Kristen pada STTII Yogyakarta; Program S3 Bidang Pariwisata di UNUD dan selesai tahun 2017; terakhir adalah sedang menempuh Program S3 Bidang Agama Hindu di IHDN Denpasar. Jabatan pengajar yang dimiliki adalah Guru Besar Arsitektur, Fakultas Teknik UNUD tahun 2000, dan menjadi dosen di bidang Kajian Budaya (1996-2010). Sejak 2017 sampai sekarang menjabat sebagai Direktur Politeknik Internasional Bali, Tanah Lot, Tabanan. Memiliki 15 karya yang telah dipublikasikan. Telah menerima penghargaan Satya Lancana Karya Satya 20 Tahun dari Presiden RI pata tahun 1999, Anugerah Citra Kartini dari Panitia ACK Jakarta tahun 2003, Satya Lancana Karya Satya 30 Tahun dari Presiden RI tahun 2004, dan Piagam Penghargaan Konferensi Guru Besar Indonesia dari Forum Intelektual Indonesia pada 16 Mei 2007. 